\title{
Alloy Chemistry and Microstructural Control to Mleet the Demands of the Automotive Stirling Engine
}

Josepth R. Stephens

National Aeronautics and Space Administration Lewis Research Center

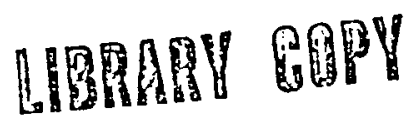

MAY 1 \& 1986

LANGLEY FESEAFCH CENTER LIRRARY, NASA HARPTON 2 VIRGINIA

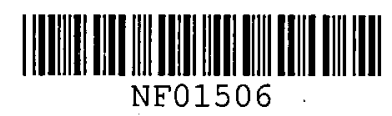

Work performed for

\section{U.S. DEPARTMENT OF ENERGY Conservation and Renewable Energy Office of Vehicle and Engine R\&D}

\author{
Prepared for \\ MiCon 1986 \\ sponsored by American Society for Testing Materials \\ Philadelphia, Pennsylvania, May 15-16, 1986
}




\section{DISCLAIMER}

This report was prepared as an account of work sponsored by an agency of the United States Government. Neither the United States Government nor any agency thereof, nor any of their employees, makes any warranty, express or implied, or assumes any legal liability or responsibility for the accuracy, completeness, or usefulness of any information, apparatus, product, or process disclosed, or represents that its use would not infringe privately owned rights. Reference herein to any specific commercial product, process, or service by trade name, trademark, manufacturer, or otherwise, does not necessarily constitute or imply its endorsement, recommendation, or favoring by the United States Government or any agency thereof. The views and opinions of authors expressed herein do not necessarily state or reflect those of the United States Government or any agency thereof.

Printed in the United States of America

Available from

National Technical Information Service

U.S. Department of Commerce

5285 Port Royal Road

Springfield, VA 22161

NTIS price codes 1

Printed copy: A02

Microfiche copy: A01

${ }^{1}$ Codes are used for pricing all publications. The code is determined by the number of pages in the publication. Information pertaining to the pricing codes can be found in the current issues of the following publications, which are generally available in most libraries: Energy Research Abstracts (ERA); Government Reports Announcements and Index (GRA and 1); Scientific and Technical Abstract Reports (STAR); and publication, NTIS-PR-360 available from NTIS at the above address. 
DOE/NASA/50112-63

NASA TM-87250

\section{Alloy Chemistry and Microstructural Control to Meet the Demands of the Automotive Stirling Engine}

Joseph R. Stephens

National Aeronautics and Space Administration

Lewis Research Center

Cleveland, Ohio 44135

Work performed for

U.S. DEPARTMENT OF ENERGY

Conservation and Renewable Energy

Office of Vehicle and Engine R\&D

Washington, D.C. 20545

Under Interagency Agreement DE-Al01-85CE50112

Prepared for

MiCon 1986

sponsored by American Society for Testing Materials

Philadelphia, Pennsylvania, May 15-16, 1986 
Alloy Chemistry and Microstructural Control to Meet the Demands

of the Automotive Stirling Engine

Joseph R. Stephens

National Aeronautics and Space Administration

Lewts Research Center

Cleveland, Oh10 44135

Abstract
The automotive Stirling engine now under development by DOE/NASA as an a)ternative to the internal combustion engine, imposes severe materials requirements for the hot portion of the engine. Materials selected must be low cost and contain a minimum of strategic elements so that availability is not a problem. Heater head tubes contain high pressure hydrogen on the inside and are exposed to hot combustion gases on the outside surface. The cylinders and regenerator housings must be readily castable into complex shapes having varying wall thicknesses and be amenable to brazing and welding operations. Also, high strength, oxidation resistance, resistance to hydrogen permeation, cyclic operation, and long-life are required. A research program conducted by NASA Lewis focused on alloy chemistry and microstructural control to achieve the desired properties over the life of the engine. Results of alloy selection, characterization, evaluation, and actual engine testing of selected materials will be presented.

KEY WORDS: Automotive Stirling engine; Alloy chemistry; Microstructure; Creep resistance; 0xidation; Hydrogen permeation; Iron-base alloys 
The Department of Energy (DOE) and NASA [1] are currently investigating the Stirling engine as an alternative power source to the internal combustion engine for automotive applications. The Stirling engine (Fig. 1) is an externally heated engine that offers the advantages of high efficiency, low pollution, low noise, and multifuel capability. Hydrogen is used as the working fluid for automotive applications in order to obtain maximum efficiency from the engine. Heat is input to the working fluid by a combustion flame impinging on the outside walls of the tubes containing the hydrogen working fluid. Current engines designed for automotive applications use tubes with a wall thickness of $0.75 \mathrm{~mm}(3.0 \mathrm{~mm} \mathrm{i.d.} \mathrm{by} 4.5 \mathrm{~mm} 0 . \mathrm{d}$.$) . The$ thin wall is required to achieve maximum heat input to the hydrogen. However, the tube material must be of sufficient strength to contain the hydrogen, which operates at high pressures and temperatures. Automotive design requirements call for a normal maximum pressure of $15 \mathrm{MPa}$, with peak pressures reaching $21 \mathrm{MPa}$ during transient conditions. Tube walls are designed for an average temperature of $820^{\circ} \mathrm{C}$, with $870{ }^{\circ} \mathrm{C}$ common on the flame side. A further requirement is that the tubes operate for a period of $3500 \mathrm{~h}$, which is approximately equivalent to the $160000-\mathrm{km}$ (100 000-mile) driving life of an engine.

The tubes currently are heated by direct exposure to a combustion flame fired by gasoline or diesel fuel. Alternative fuels such as alcohol and shale ofl derivatives may be considered for future applications. Oxidation and corrosion resistance is one of several criteria for selecting heater-head-tube alloys to withstand the extreme operating requirements of the stirling engine. A second criterion is the resistance of the tube material to hydrogen permeation so that hydrogen recharging of the engine is required in excess of 6 month intervals. Finally, the creep-rupture strength for $3500 \mathrm{~h}$ life is a determining factor in selecting a heater tube alloy. These criterfa are 
interrelated. For example, excessive scale spalling due to oxidation/corrosion will reduce the tube wall thickness and lead to premature fallure caused by the high-pressure hydrogen rupturing the tubes or permeating rapidly through the tube walls. Prototype engines and initial madels of experimental automotive engines use $\mathrm{N}-155$ (Multimet) for heater head tubes. However, this iron-base alloy contains 20 percent cobalt, a costly and strategic metal. Efforts are currently under way by NASA [2-7] and the contractors on this program, Mechanical Technology Inc. (MTI) and United Stirling Sweden (USAB), to identify substitutes for $\mathrm{N}-155$. The primary emphasis is on high-strength austenitic iron-base alloys although a 1 imited number of nickel-base superalloys are under consideration. As part of the evaluation of candidate substitute alloys the oxidation and corrosion resistance has been determined for 16 alloys [8]. Hydrogen permeation coefficients have been determined for most of those alloys [9], and strength properties have been measured by creep testing in air [2] and hydrogen [10]. Further, endurance testing in a materials simulator rig and engine testing have been used to characterize selected candidate heater tube alloys $[3,6,9]$.

The purpose of this paper is to describe the effects of alloy chemistry and microstructure on the oxidation/corrosion behavior and resistance to hydrogen permeability of candidate alloys.

Procedure

Materials

Twenty alloys (14 iron base, five nickel base, and one cobalt base) were evaluated for their oxidation and corrosion resistance, hydrogen permeability, and endurance under conditions of temperature and environment anticipated for automotive Stirling engines. The chemical compositions of the alloys are listed in Table 1. All of the alloys are commerclally avallable except AL-EX-20, an experimental alloy supplied by Allegheny Ludlum Steel Company. 
Iron-base alloys are the primary candidates for automotive Stirling engine applications because their raw material costs are lower than those for nickel-base and cobalt-base alloys. Nickel-base alloys are considered as possible candidates in the event a less expensive iron-base alloy cannot be identified that will meet all of the requirements of the Stiriing engine. Cobalt-base alloys are not under consideration for automotive Stirling engine applications because of the high cost of cobalt, its limited avallability, and its status as a strategic material (more than 95 percent of the cobalt used in the United States is imported). However, one cobalt-base alloy (HS-188) was included in this investigation as a comparison with the iron-and nickel-base a11oys.

For oxidation testing, test coupons 1.27 by $2.54 \mathrm{~cm}$, and generally 0.8 to $1.6 \mathrm{~mm}$ thick, with a $0.3-\mathrm{cm}-d$ lameter hanger hole, were cut from the alloy sheet material. For hydrogen permeability and endurance testing the alloys used in this study were obtained commercially in the form of tubing with an outside diameter of $4.5 \mathrm{~mm}$ and an inside diameter of $3.0 \mathrm{~mm}$ (the size used in current prototype engines). Four of the tubing alloys were weld-drawn and the others were seamless tubing. The weld-drawn alloys were $\mathrm{N}-155,19-9 \mathrm{DL}$, Incone $1718(w d)$ and HS-188.

Stirling Engine Simulator Materials Test Rig

The stirling engine simulator rig used in this program was designed and fabricated at the NASA Lewis Research Center; it consists primarily of a combustion gas heating chamber (Fig. 2) with auxiliary heating, control, and gas management systems. The rig and its operation have been described in detail [3]. The rig was fired with natural gas for initial ignition and then with diesel fuel throughout the test run. Duplicate oxidation-corrosion test specimens were suspended by platinum wires from the hairpin turns of the tubes shown in Fig. 2. The specimens were heated to the desired $820^{\circ} \mathrm{C}$ test 
temperature (automotive Stirling engine temperature) by the combustion flame flowing over them. The rig was used primarlly as a means of ranking candidate heater-head-tube alloys $[3,6,9]$. The oxidation-corrosion testing was conducted simultaneously with a $3500-h$ endurance and permeability run of tubing alloys. An endurance run consisted of a series of 5 -h cycles to obtain the required $3500 \mathrm{~h}$ of test time to simulate the minimum life of an automotive engine. A typical heating cycle consisted of a 6 - to 10 -min preheat to get to the operating temperature, a 5-h hold at temperature, and a $1-h$ cooldown to near room temperature. The change in specific weight $\Delta W / A$ with time $t$ for the oxidation coupons was fitted by least squares [11] to equation (1).

$$
\frac{\Delta W}{A}=k_{1}^{1 / 2} t^{1 / 2}-k_{2} t \pm S E E
$$

where $k_{1}$ is an oxide growth constant comparable to a parabolic oxidation scaling constant, $k_{2}$ is an oxide spalling constant, and SEE is the standard error of estimate. An oxidation attack parameter $k_{a}[11]$ was derived from equation (1) and is defined as

$$
k_{a}=k_{1}^{1 / 2}+10 k_{2}
$$

The original hydrogen pressure in the tubes and the pressure at the end of a $5-h$ cycle were used to calculate the hydrogen permeability coefficient, $\phi$, using the equation:

$$
P=P_{0}^{1 / 2}-\frac{\phi A P_{s} T t}{2 L V T_{s}}
$$

where

$\mathrm{P} \quad$ pressure in closed system, MPa

$\mathrm{P}_{0}$ original pressure, $\mathrm{MPa}$

A permeated area, $\mathrm{cm}^{3}$

$\mathrm{P}_{\mathrm{S}}$ standard pressure, MPa

$T$ temperature of system, $K$ 
$t$ time, sec

L membrane thickness, cm

$v$ volume of system, $\mathrm{cm}^{3}$

$T_{s}$ standard temperature, $K$

\section{Results}

Stiriing Engine Simulator 0xidation and Corrosion Tests

Weight change. - The alloys could be categorized into four groups on the basis of specific weight change data. Alloys in group I had excellent oxidation and corrosion resistance, and their specific weight change was positive (weight gain) throughout the 3500-h test. Group I comprised the five alloys CG-27, Incoloy 800 , HS-188, N-155, and Incone 7718 . Three of the alloys, CG-27, Incoloy 800 , and HS-188, did not exhibit any significant spalling during testing in the Stirling engine simulator rig. Final average specific weight change (Fig. 3) ranged from 1.4 to $0.17 \mathrm{mg} / \mathrm{cm}^{2}$ for $\mathrm{CG}-27$ to Inconel 718 , respectively.

A second group of alloys is considered to have relatively good oxidation and corrosion resistance under simulated stirling engine operating conditions. The five alloys in group II in order of increasing final weight loss are RA-330, Sanicro 31H, Sanicro 32, 12RN72, and 253 MA. Final average specific weight change (Fig. 4) ranged from -0.54 to $-6.0 \mathrm{mg} / \mathrm{cm}^{2}$ for $\mathrm{RA}-330$ to $253 \mathrm{MA}$, respectively.

The third group of alloys, 316 stainless steel, W-545, A-286, and Nitronic 40 is considered to have fair to poor oxidation and corrosion resistance on the basis of specific-weight-change-versus-time data. Final average specific weight change (Fig. 5) ranged from -22.8 to $-41.8 \mathrm{mg} / \mathrm{cm}^{2}$ for 316 stainless steel to Nitronic 40 , respectively.

A final group of alloys, consisting of 19-9DL and AL-EX-20, exhibited catastrophic oxidation and corrosion behavior upon rig testing. Spaling 
began after only a very short time into the test and excessive weight loss occurred after $500 \mathrm{~h}$ of cyclic testing. The tests were terminated before the $3500-h$ goal because of the unacceptable oxidation and corrosion resistance of these alloys.

Attack parameter $K_{a}$ - Oxidation and corrosion weight-change-versus-time data were fitted to the paralinear equation (eq. (1)). For three of the alloys, HS-188, Incoloy 800, and CG-27, where no spalling was observed, the attack parameter was calculated from equation (2) with $k_{2}=0$. The remaining 13 alloys also derived their attack parameters from equation (2) but with values of $k_{2}$ included. For alloys $19-9 \mathrm{DL}$, Nitronic 40, and AL-EX-20 the $k_{1}^{1 / 2}$ term dropped out so that $k_{a}=20 k_{2} t$ was used. Figure 6 is a summary plot of calculated $k_{a}$ values for the alloys. Values of $k_{a}$ are plotted on a log scale in decreasing order of oxidation and corrosion resistance based on the highest values of the duplicate specimens. The attack parameter ranged from 0.011 for HS-188 to 12.49 for 19-9DL, or over three orders of magnitude. Examination of the $K_{a}$ values in Fig. 6 suggested that the alloys could again be categorized into four groups. Group I comprised the alloys HS-188, Sanicro $31 \mathrm{H}$, Incone 1 718, Incoloy 800, $\mathrm{N}-155, \mathrm{CG}-27$, and $\mathrm{RA}-330$, with $\mathrm{K}_{\mathrm{a}}$ ranging from 0.011 for HS-188 to 0.031 for RA-330. Group II comprised the three alloys Sanicro 32, 12RN72, and $253 \mathrm{MA}$, with $\mathrm{K}_{\mathrm{a}}$ values of $0.098,0.110$, and 0.159 , respectively. Group III comprised the alloys A-286, W-545, 316 stainless steel, and Nitronic 40, with $k_{a}$ ranging from 0.370 to 0.659 . Group IV comprised AL-EX-20,, with a $K_{a}$ of 4.68 , and 19-9DL, with a $K_{a}$ of 12.49. This grouping was somewhat arbitrary, but corresponded to the previous grouping based on final weight change. The only exception was for RA-330, which experienced a net weight loss and was placed in group II 
(Fig. 4) but has a $K_{a}$ value similar to those for the other five alloys in group I.

X-ray diffraction. - The x-ray diffraction data from the specimen surface after testing are summarized in Table 2 by rank of the alloy in decreasing $x$-ray intensity. In general, the most oxidation and corrosion resistant alloys formed nearly pure $\mathrm{Cr}_{2} \mathrm{O}_{3}$ as either the most or secondmost intense oxide. The $\mathrm{Cr}_{2} \mathrm{O}_{3}$ oxide is listed as a sesquioxide, $d(024)=0.1818 \mathrm{~nm}$ in Table 2. Because Fe went into solution as $\mathrm{Fe}_{2} \mathrm{O}_{3}$, the value of $d$ increased. As the $d$ value approached $0.1839 \mathrm{~nm}$, the oxide became essentially pure $\mathrm{Fe}_{2} \mathrm{O}_{3}$. Chromite spinel with $\mathrm{a}_{0}$ ranging from 0.835 to $0.840 \mathrm{~nm}$ also formed on most of the alloys during oxidation and corrosion testing. This chromite spinel appeared to be innocuous. Alloy A-286 showed another spinel with $a_{0}=0.830 \mathrm{~nm}$ along with a lower sesquioxide with $d=$ $0.1813 \mathrm{~nm}$, and also NiO was formed. Alloy 19-9DL, which oxidized catastrophically, formed as its two strongest oxides a spinel with $a_{0}=$ $0.840 \mathrm{~nm}$ and the desirable oxide $\mathrm{Cr}_{2} \mathrm{O}_{3}$ with $\mathrm{d}=0.1821 \mathrm{~nm}$.

Metallography. - Microstructures of selected alloy specimens after the 3500-h test are shown in Fig. 7. Alloy CG-27 (Fig. 7(a)) had an adherent oxide scale on the specimen surface. Alloy Inconel 718 (Fig. $7(\mathrm{~b})$ ) had a thin, adherent oxide scale with a small depletion zone present in this alloy. Sanicro 32 (Fig. $7(\mathrm{c})$ ) formed large voids in the depletion zone. Severe grain boundary attack occurred in W-545 (Fig. $7(d)$ ) and resulted in almost total consumption of the alloy matrix beneath the surface oxide.

Electron microprobe analysis. - Alloy CG-27, a group I alloy, was examined because it had excellent oxidation resistance and contained the least chromium of the 16 alloys tested in the rig. The distribution of the major alloying elements and oxygen in the oxide scale and the adjacent metal substrate of CG-27 (Fig. 8) showed the surface oxide to be rich in iron, 
nickel, and to a lesser extent aluminum. Beneath this oxide layer was a thin, continuous oxide layer rich in chromium and titanium. Adjacent to the chromium-rich intermediate scale was an aluminum-rich oxide next to the metal substrate, which exhibited a wide zone of internally oxidized aluminum-rich, and somewhat fewer titanium-rich, protrusions.

Metallographic results for the group III alloy W-545 (Fig. 7(d)) indicated a large surface scale consisting of a porous oxide. Results from electron microprobe analyses (Fig. 9) showed an outer oxide rich in iron, nicke1, and chromium. 0xygen had penetrated uniformly into this alloy to a substantial depth. The oxide formed appeared to be rich in nickel with some chromium. Iron was depleted from this area, but discrete areas of molybdenum were observed near the surface. Aluminum and titanium did not appear to enter into the oxidation process of this alloy. The composition of W-545 is similar to that of CG-27 except for the large difference in aluminum content. This suggests that aluminum makes a major contribution to the oxidation resistance of CG-27 and that its low concentration in $W-545$ may explain the poor oxidation resistance of that alloy.

Stirling Engine Simulator Hydrogen Permeation and Endurance Tests

Hydrogen permeability. - Previous measurements of hydrogen permeation during cyclic testing in the simulator rig [12] indicated that hydrogen loss was rapid through the thin wall tubes of alloy $\mathrm{N}-155$. Hydrogen pressure decay curves are shown in Fig. 10(a) for selected $5 \mathrm{~h}$ cycles in an $100 \mathrm{~h}$ test. It should be noted that pressure loss is rapid and is most severe for the first $5 \mathrm{~h}$ cycle. The slight improvement for the remaining cycles is attributed to the formation of an oxide scale on the exterior surface of the tubes. It was shown previously [13] that a thin $(0.02 \mathrm{~mm})$ carbide could form on the tubes internal surface in an engine presumably due to oil leaking into the heater head. This carbide layer resulted in reducing the permeability rate of 
hydrogen from the engine. A program was undertaken at NASA Lewis [12] to investigate various dopants such as $\mathrm{CO}, \mathrm{CO}_{2}, \mathrm{CH}_{4}$, etc. to form carbide or oxide surface layers on the tubes internal surfaces to act as a barrier to hydrogen permeability. The effects of 1 vol $\% \mathrm{CO}_{2}$ in hydrogen are shown in Fig. 10(b) for alloy $\mathrm{N}-155$. The results suggest that the oxide that formed on the internal surfaces was effective in reducing hydrogen loss from the tubes. Hydrogen permeability coefficients were calculated from the pressure decay curves using equation (3). Permeablitty coefficients as a function of rig exposure time are plotted in Figs. 11 to 13 for iron, nickel, and cobalt-base alloys, respectively. For iron-base alloys, hydrogen permeability coeffictents vary over two orders of magnitude while for the five nickel-base alloys a variation of about a factor of two is noted. A comparison of the hydrogen permeability coefficients after $250 \mathrm{~h}$ testing (since some alloys did not survive much longer) is shown in Fig. 14. In general the nickel-base alloys exhibited lower permeability coefficients than the iron-base alloys. An iron-base alloy, CG-27 was an exception to this general observation. Endurance testing. - Endurance testing was also conducted on the tube alloys by filling with $15 \mathrm{MPa}$ helium. Since helium did not permeate the tube walls, a constant pressure (stress) was maintained. This test is much more severe than actual engine operation where the mean pressure is near 4 MPa, but does provide an effective method for ranking the strengths of the alloys under simulated engine conditions. A comparison of rupture lives is shown in Fig. 15. Only CG-27 and Pyromet 901 survived the $3500 \mathrm{~h}$ test. It should be noted for alloy Inconel 718 that seamless tubing (Inconel 718(a)) had a much longer life than the weld-drawn tubing (Inconel $718($ wd)). Cold working of 12 RN72 (cW) reduced the rupture life from the standard heat treated condition. Metallography. - Microstructures of selected alloys are shown in Fig. 16. Alloy CG-27 is shown before and after exposure. The oxide film on 
both internal and exterior surfaces is evident for the hydrogen and 1 percent $\mathrm{CO}_{2}$ containing tube (Fig. 16(a)). Alloy Inconel 625 (Fig. 16(b)) exhibited external scale cracking after cyclic exposure.

Discussion of Results

Some insight into the excellent oxidation and corrosion behavior of CG-27 can be gained from the electron microprobe results. The chromium distribution shows that CG-27 had a chromium-rich oxide layer ranging in thickness from about 3 to $4 \mu \mathrm{m}$. The poorer oxidation behavior of group II and III alloys was characterized by chromium-rich oxide layers about $8 \mu \mathrm{m}$ thick (group II alloys) and from 20 to $35 \mu \mathrm{m}$ thick (group III alloys) [8]. All 16 alloys studied herein formed $\mathrm{Cr}_{2} \mathrm{O}_{3}$ chromite spinels as their major oxides. The thin, adherent oxide formed by the group I alloys CG-27 and Incoloy 800 (not shown) is believed to be a major contributor to the oxidation resistance of these alloys.

Further comparison of the alloys characterized by electron microprobe techniques indicated that iron and nickel were present as a thin outer oxide in group $I$ alloys. In contrast, in group II alloys and especially in group III alloys, iron and nickel were observed as thick, discrete areas of oxide that were in some cases ready to spall from the specimen. Evidently in group I alloys the iron and nickel oxides formed early in the 3500-h test, and then oxide formation of the more reactive alloying elements took over the oxidizing process. The thicker oxides and higher spalling rates in particular for group III alloys (specific weight losses of 23 to $42 \mathrm{mg} / \mathrm{cm}^{2}$ as compared with little or no weight loss for group 1 alloys) suggest that iron and nickel oxides formed throughout the 3500-h test.

Particular interest was focussed on the apparent roles of the more reactive oxide-forming alloying elements aluminum and titanium contained in some of the alloys. In CG-27 internal oxidation of aluminum to a depth of 
approximately $10 \mu \mathrm{m}$ below the oxide-metal interface was evident. In addition, aluminum was present in the surface oxide, and a thin oxide layer rich in aluminum existed adjacent to the metal substrate. A similar, though not as evident, distribution of aluminum occurred in Incoloy 800 . Incoloy 800 contains 0.38 wt $\%$ aluminum as compared with 1.5 wt $\%$ in CG-27. A thin, discontinuous aluminum-rich oxide layer near the oxide-metal interface and grain boundary oxides were previously noted for Sanicro 32. Titanium, at a concentration of 2.5 wt \% in CG-27, appeared to be associated with aluminum in the oxide scales and as internally oxidized. In contrast, for the group III alloy w-545, which contains slightly more titanium (2.85 wt \%) but much less aluminum ( 0.2 wt $\%$ ), titanium does not preferentially oxidize.

The role of reactive elements such a yttrium, scandium, cerium, zirconium, and hafnium in improving oxide scale adherence particularly for $\mathrm{Fe}-\mathrm{Cr}-\mathrm{AL}, \mathrm{N} i-\mathrm{Cr}-\mathrm{Al}$, and $\mathrm{Co}-\mathrm{Cr}-\mathrm{Al}$ alloys has been investigated in much detail [14-19]. The standard free energies of oxide formation of these reactive elements are more negative than those for iron, nickel, cobalt, chromium, and aluminum. Small additions ( $<1$ at $\%$ ) of these elements have been shown to dramatically improve oxide scale adherence and to reduce spalling in cyclic oxidation. The exact mechanism by which such an improvement occurs is not agreed upon by investigators in this field. For example, yttrium and scandium have been reported to increase oxide growth rates by forming rapid diffusion paths along yttria and scandia stringers [14]. Increased grain boundary transport of oxygen has been demonstrated by ${ }^{18} 0$ tracer studies on $\mathrm{Ni}-\mathrm{Cr}-\mathrm{Al}$ alloys with zirconium additions [15]. The resulting oxide adherence has been attributed $[14,15,18]$ to (1) mechanical oxide pegging; (2) stress-strain accommodations at the oxide-matrix interface; (3) increased chemical bonding across the interface; and (4) a vacancy sink mechanism that precludes void formation at the oxide-metal interface, which would promote spalling. 
It is postulated that for the alloys studied herein, aluminum plays a role similar to that of the reactive elements discussed previously. Aluminum has a more negative standard free energy of oxide formation than do the major alloying constituents of the candidate heater-head-tube alloys such as fron, nickel, and chromium. The internal aluminum oxidation suggests that controlling the inward oxygen diffusion plays a major role in the oxidation of CG-27 and probably Incoloy 800 [8]. Although the remaining group I alloys were not studied by electron microprobe techniques, the reactive elements niobium in $\mathrm{N}-155$, niobium and aluminum in Incone 1718 , and lanthanum in HS-188 probably play a role similar to that of aluminum in the two alloys that were examined. - The results further suggest that although 0.4 wt $\%$ aluminum is adequate to be effective in promoting good scale adherence (Incoloy 800 , Sanicro 32, Sanicro $31 \mathrm{H}$, and Inconel 718), a concentration of 0.2 wt \% aluminum such as exists for W-545, Fig. 9 and A-286 is insufficient to improve the oxidation behavior of these alloys. It is not clear from this study which of the previousiy suggested models for oxide scale adherence is to be preferred.

The factors effecting oxidation/corrosion behavior of the alloys is also important in minimizing hydrogen permeation through the tube walls. Formation of an adherent oxide film on the internal surface of the heater head tubes is required to reduce the hydrogen loss by permeation. Alloys with low oxidation/corrosion attack parameters, $K_{a}$ also had low hydrogen permeability coefficents, $\phi$. Results presented herein have clearly shown the importance of alloy composition, specifically the presence of the more reactive elements such as $A 1, T H$, and $L a$ as a key to controling oxidation/corrosion behavior of the alloys. This, in turn, is reflected in the resulting microstructure where thin oxide layers containing the reactive 
elements are desirable for long-life, low-hydrogen permeability heater head tube alloys.

\section{Application of Results}

Based on the results of these tests alloys CG-27, 12RN72, Sanicro 32, and Inconel 625 were selected for engine testing. Engine testing under accelerated conditions exceeded $2000 \mathrm{~h}$ or an equivalent $3300 \mathrm{~h}$ of urban-highway driving. Only alloy CG-27 did not fall by creep rupture in the engine test [20]. Alloy CG-27 has been selected as the heater head tube material for the automotive Stirling engine because of its good creep-rupture (endurance) strength, resistance to oxidation and corrosion, and resistance to hydrogen permeation as a result of forming a thin, tenacious oxide using $\mathrm{CO}_{2}$ doped hydrogen.

\section{Concluding Remarks}

This study has shown that chemistry and microstructure of heater head tube alloys which develops during operation of the engine and in simulated tests play an important role in alloy selection for the automotive stirling engine. Specifically the following features were shown to be important:

1. The presence of a sufficient amount (about $0.4 \mathrm{wt} \%$ ) of the reactive metal aluminum in iron-base alloys leads to a microstructure characterized by a thin, adherrent oxide scale rich in aluminum plus internal oxidation of aluminum which impedes inward diffusion of oxygen.

2. The thin, adherrent oxide scales on both the combustion gas side and the $\mathrm{CO}_{2}$ doped hydrogen side of the tubes act as barriers to hydrogen permeation.

3. The thin, adherrent oxides characterized by no or very little spalling and metal loss lead to utilization of the full cross-sectional area of the tube alloy to provide the required strength for the $3500 \mathrm{hr}$ life of an engine. 


\section{REFERENCES}

1. Brogan, J.J., "Highway Vehicle Systems Program Overview," Highway Vehicle Systems Contractors Coordination Meeting, CONF-771037, Dept. of Energy, Washington, D.C., 1978, pp. 3-5.

2. Witzke, W.R., and Stephens, J.R., "Creep-Rupture Behavior of Seven Iron-Base Alloys After Long Term Aging at $760{ }^{\circ} \mathrm{C}$ in Low Pressure Hydrogen," NASA TM-81534, National Aeronautics and Space Administration, Washington, D.C., 1980.

3. Misencik, J.A., "Evaluation of Candidate Stirling Engine Heater Tube Alloys for 1000 Hours at $760{ }^{\circ} \mathrm{C}$," NASA TM-81578, National Aeronautics and Space Administration, Washington, D.C., 1980.

4. Stephens, J.R., in Environmental Degradation of Engineering Materials in Hydrogen, M.R. Louthan Jr., R.P. McNitt and R.D. Sisson Jr., Eds., Virginia Polytechnic Institute and State University, Blacksburg, VA, 1981, pp. 123-132.

5. Schuon, S.R., and Misencik, J.A., "Effect of Oxide Films on Hydrogen Permeability of Candidate Stirling Engine Heater Head Tube Alloys," NASA TM-82824, National Aeronautics and Space Administration, Washington, D.C., 1982.

6. Misencik, J.A., "Evaluation of Candidate Stirling Engine Heater Tube Alloys at $820^{\circ} \mathrm{C}$ and $860^{\circ} \mathrm{C}, "$ NASA TM-82837, National Aeronautics and Space Administration, Washington, D.C., 1982.

7. Stephens, J.R., Cronin, M.T., and Skog, E., in proceedings of the Twentieth Automotive Technology Development, Contractors' Coordination Meeting, SAE P-120, Society of Automotive Engineers, New York, 1983, pp. 103-113. 
8. Stephens, J.R., and Barrett, C.A., "Oxidation and Corrosion Resistance of Candidate Stirling Engine Heater-Head-Tube Alloys," NASA TM-83609, National Aeronautics and Space Administration, Washington, D.C., 1984.

9. Misencik, J.A., and Titran, R.H., "Evaluation of Candidate Stirling Engine Heater Tube Alloys After 3500 Hours Exposure to High Pressure Doped Hydrogen or Helium," NASA TM-83782, National Aeronautics and Space Administration, Washington, D.C., 1984.

10. Bhattacharyya, S., and Titran, R.H., Journal of Materials for Energy Systems, Vol. 7, No. 2, Sept. 1985, pp. 123-136.

11. Barrett, C.A., and Lowe11, C.E., Journal of Testing and Evaluation, Vo1. 10, No. 6, Nov. 1982, pp. 273-278.

12. Misencik, J.A., "Evaluation of Dopants in Hydrogen to Reduce Hydrogen Permeation in Candidate Stirling Engine Heater Head Tube Alloys at $760^{\circ}$ and $820{ }^{\circ} \mathrm{C}, "$ NASA TM-82920, National Aeronautics and Space Administration, Washington, D.C., 1982.

13. Stephens, J.R., in Sixteenth Summary Report, Highway Vehicle Systems Contractor's Coordination Meeting, CONF-7904105, Dept. of Energy. Washington, D.C., 1979, pp. 262-272.

14. Tien, J.K., and Pettit, F.S., Metallurgical Transactions, Vol. 3, No. 6, June, 1972, pp. 1587-1599.

15. Allam, I.M., Whittle, D.P., and Stringer, J., Oxidation of Metals, Vo1. 13, No. 4, Aug. 1979, pp. 381-401.

16. Smialek, J.L., Journal of Electrochemical Society, Vol. 126, No. 12, Dec. 1979, pp. 2275-2276.

17. Khan, A.S., Lowe11, C.E., and Barrett, C.A., Journal of the Electrochemical Society, Vol. 27, no. 3, Mar. 1980, pp. 670-679.

18. Barrett, C.A., Khan, A.S., and Lowe11, C.E., Journal of the Electrochemical Society, Vol. 128, No. 1, Jan. 1981, pp. 25-32. 
19. Reddy, K.P.R., Smialek, J.L., and Cooper, A.R., Oxidation of Metals, Vol. 17, Nos. 5/6, June 1982, pp. 429-449.

20. Skog, E., Cronin, M., and Stephens, J., in Proceedings of the Twenty-Second Automotive Technology Development Contractor's Coordination Meeting, SAE P-155, Soclety of Automotive Engineers, New York, 1985 , pp. $175-180$. 
TABLE 1 -- CHEMICAL COMPOSIIION OF COMMERCIAL ALLOYS

\begin{tabular}{|c|c|c|c|c|c|c|c|c|c|c|c|c|c|}
\hline \multirow[t]{2}{*}{ Alloy } & \multicolumn{13}{|c|}{ Composition, wt $\phi$} \\
\hline & $\mathrm{Fe}$ & $\mathrm{Cr}$ & $\mathrm{Ni}$ & Co & $\mathrm{Mn}$ & $\mathrm{Si}$. & Mo & Nb. & W & Al & $T i$ & c & 0ther \\
\hline & \multicolumn{13}{|c|}{ Iron-base alloys } \\
\hline$N-155$ & 30 & 21 & 20 & 20 & 1.5 & 0.5 & 3.0 & 1.0 & 2.5 & --- & --- & 0.15 & $0.15 \mathrm{~N}$ \\
\hline $\mathrm{CG}-27$ & 38 & 13 & 38 & -- & .1 & .1 & 5.5 & .6 & -- & 1.5 & 2.5 & .05 & $.01 \mathrm{~B}$ \\
\hline$R A-330^{a}$ & 43 & 19 & 35 & -- & 1.5 & 1.3 & -- & --- & -- & --- & ---- & .05 & --- \\
\hline Sanicro 32 & 43 & 21 & 31 & -- & .6 & .47 & -- & --- & 2.8 & .4 & .4 & .89 & $-\cdots$ \\
\hline Sanicro $31 \mathrm{H}$ & 46 & 21 & 31 & -- & .6 & .55 & -- & --- & |-- & .4 & .5 & .07 & $.02 \mathrm{~N}$ \\
\hline Incoloy 800 & 46 & 21 & 32 & -- & .75 & .5 & -- & --- & -- & .38 & .38 & .05 & 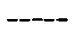 \\
\hline $12 \mathrm{RN} 72$ & 47 & 19 & 30 & -- & 1.7 & .28 & 1.4 & --- & -- & --- & .5 & .1 & $.02 \mathrm{~N}$ \\
\hline A-286 & 53 & 15 & 26 & - & 1.4 & .4 & 1.25 & -- & $-\infty$ & .2 & 2.15 & .05 & $.26 \mathrm{~V}$ \\
\hline$W-545$ & 54 & 14 & 26 & - & 1.5 & .4 & 1.5 & -- & -- & .2 & 2.85 & .08 & $.08 \mathrm{~B}$ \\
\hline Nitronic $40^{\mathrm{a}}$ & 64 & 21 & 6.5 & - & 9.0 & --- & -- & -- & -- & --- & --- & .04 & $.30 \mathrm{~N}$ \\
\hline $253 \mathrm{MA}$ & 66 & 21 & 11 & -- & .4 & 1.7 & .04 & --- & -- & - & - & .09 & $.2 \mathrm{~N}$ \\
\hline $\begin{array}{c}316 \text { Stainless } \\
\text { steel }\end{array}$ & 66 & 18 & 13 & -- & 2.0 & 1.0 & 2.5 & --- & --- & $-\cdots$ & $-\therefore$ & .08 & ---- \\
\hline $19-9 D L$ & 67 & 19 & 9 & -- & 1.1 & .6 & 1.2 & .4 & 1.2 & -- & .3 & .3 & ----- \\
\hline$A L-E X-20^{\alpha}$ & 70 & 5 & 1.0 & -- & 20 & .42 & -- & -- & - & 3.15 & -- & .02 & $-\cdots$ \\
\hline & & & & & Nick & Dase & $110 y$ & & & & & & \\
\hline Incone $750^{\circ}$ & 8 & 16 & 71 & -- & 0.16 & 0.23 & -- & 0.05 & |-- & 0.72 & 2.5 & 0.05 & ----- \\
\hline Inconel $625^{\mathrm{b}}$ & 3 & 22 & 61 & - & .15 & .3 & 9.0 & 4.0 & --- & .2 & 0.2 & 0.05 & - \\
\hline Inconel $601^{\mathrm{b}}$ & 14 & 23 & 60 & -- & .5 & .2 & -- & -- & -- & 1.4 & --- & .05 & ----- \\
\hline Inconel 718 & 18 & 18 & 53 & - & .2 & .3 & 3.1 & 5.0 & - & .4 & .9 & .04 & ---- \\
\hline Pyromet $901^{b}$ & 34 & 12 & 45 & -- & .10 & .19 & 5.9 & -- & - & $\ldots$ & 2.6 & .03 & $-\ldots$ \\
\hline & & & & & Coba & & 11 & & & & & & \\
\hline HS-188 & 1.5 & 22 & 22 & 40 & -- & ---- & -- & --- & 14 & --- & --- & 0.08 & $0.08 \mathrm{La}$ \\
\hline
\end{tabular}

${ }^{\mathrm{a} E v a l u a t e d}$ in hydrogen permeability and endurance testing only.

Evaluated in oxidation/corrosion testing only. 
TABLE 2 -- X-RAY DIFFRACTION DATA OF SPECIMEN SURFACE AFTER 3500-h TEST IN ORDER OF DECREASING INTENSITY

[Values of $d$ and $a_{0}$ are in nanometers.]

\begin{tabular}{|c|c|c|c|c|c|c|c|}
\hline Rank & Alloy & $\begin{array}{l}\text { Chromium } \\
\text { content, } \\
\text { wt } \delta\end{array}$ & 1 & 2 & & 3 & 4 \\
\hline 1 & $\mathrm{HS}-188$ & 22 & 0.1818 Sesquioxide & $\mathrm{a}_{0}=0.840 \mathrm{~s}$ & Spinel & $\mathrm{Mn}_{2} \mathrm{O}_{3}$ & $0.408\left(\mathrm{SiO}_{2}\right)$ \\
\hline 2 & Sanicro $31 \mathrm{H}$ & 21 & $a_{0}=0.840$ & 0.1819 & & $\mathrm{SiO}_{2}$ & $\left(\mathrm{Mn}_{0.983} \mathrm{Fe}_{0.017}\right)_{2} \mathrm{O}_{3}$ \\
\hline 3 & Inconel 718 & 18 & $a_{0}=0.835$ & 0.1822 & & $0.410\left(\mathrm{SiO}_{2}\right)$ & 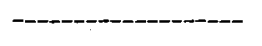 \\
\hline 4 & Inconel 800 & 21 & $a_{0}=0.840$ & 0.1819 & & $\mathrm{Mn}_{2} \mathrm{O}_{3}$ & $0.409\left(\mathrm{SiO}_{2}\right)$ \\
\hline 5 & $N-155$ & 21 & $a_{0}=0.840$ & 0.1826 & & $0.411\left(\mathrm{SiO}_{2}\right)$ & 0.272 \\
\hline 6 & CG-27 & 13 & $a_{0}=0.835 \quad$ Spinel & 0.1821 & Sesquioxide & 0.1841 Sesquioxide & Trirutile, $d=0.330$ \\
\hline 7 & $R A-330$ & 19 & $a_{0}=0.840$ & 0.1818 & & $\mathrm{Mn}_{2} \mathrm{O}_{3}$ & - \\
\hline 8 & Sanicro 32 & 21 & $a_{0}=0.840$ & 0.1819 & & $\mathrm{SiO}_{2}$ & $\left(\mathrm{Mn}_{0.983} \mathrm{Fe}_{0.017}\right)_{2} \mathrm{O}_{3}$ \\
\hline 9 & $12 R N 72$ & 19 & $a_{0}=0.840$ & 0.1819 & & $\left(\mathrm{Mn}_{0.983}{ }^{\mathrm{Fe}_{0.017}}\right)_{2} \mathrm{O}_{3}$ & $\mathrm{SiO}_{2}$ \\
\hline 10 & $253 \mathrm{MA}$ & 21 & 0.1839 Sesquioxide & $a_{0}=0.835 s$ & Spinel & $\mathrm{SiO}_{2}$ & 0.1812 Sesquioxide \\
\hline 11 & $A-286$ & 15 & $a_{0}=0.830$ Spinel & 0.1813 & & $\mathrm{NiO}$ & ---- \\
\hline 12 & $W-545$ & 14 & $a_{0}=0.840$ Spine $i$ & 0.1849 & Sesquioxide & - & -- \\
\hline 13 & $\begin{array}{l}316 \text { Stainless } \\
\text { steel }\end{array}$ & 18 & 0.1842 Sesquioxide & 0.1824 & & $a_{0}=0.845$ Spinel & $\mathrm{Mn}_{2} \mathrm{O}_{3}$ \\
\hline 14 & Nitronic 40 & 21 & $a_{0}=0.840$ Spine 1 & 0.1843 & & ----- & \\
\hline 15 & $A L-E X-20$ & 5 & 0.1839 Sesquioxide & $a_{0}=0.840 s$ & Spinel & $\mathrm{Mn}_{2} \mathrm{O}_{3}$ & $-\cdots$ \\
\hline 16 & 19-9DL & 19 & $\mathrm{a}_{0}=0.840$ Spinel & 0.1821 Sesqui & dioxide & 0.1843 Sesquioxide & \\
\hline
\end{tabular}




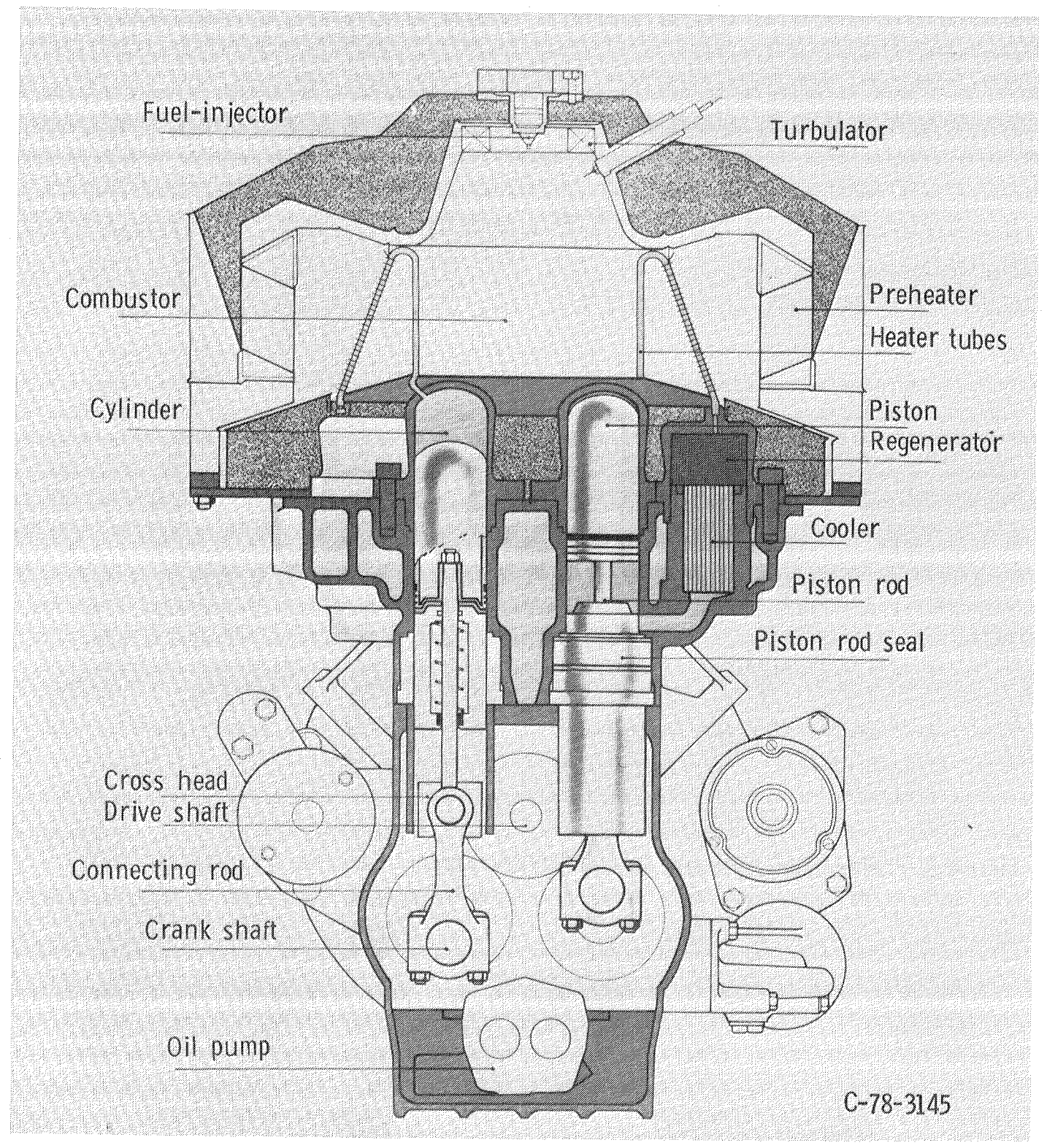

Figure 1. - Schematic representation of automotive Stirling engine. 


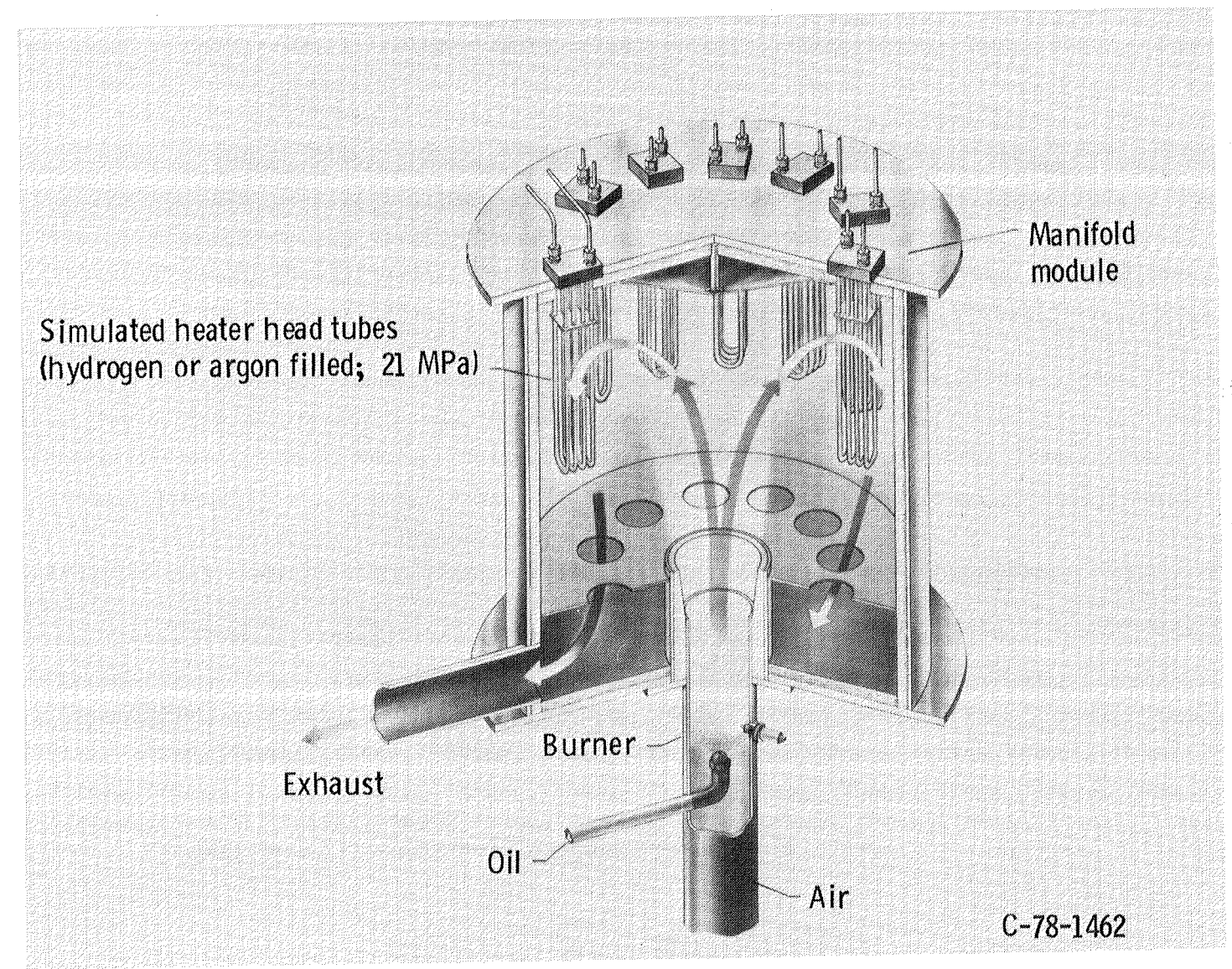

Figure 2. - Schematic representation of Stirling engine materials simulator test rig. 


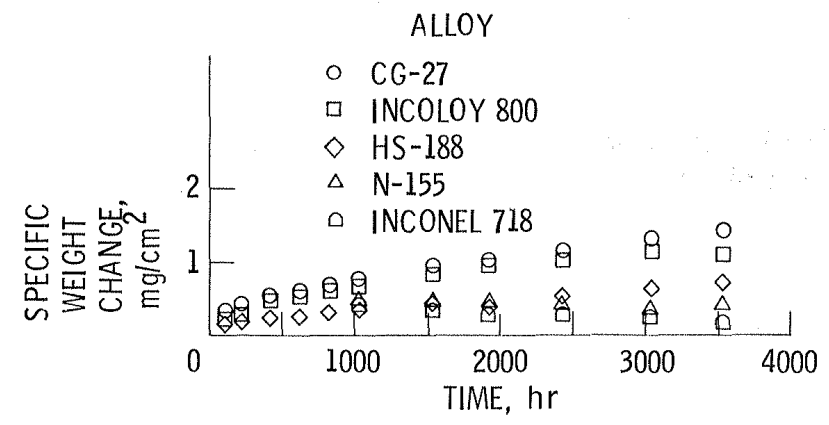

Figure 3. - Specific weight change data for group I alloys tested at $820^{\circ} \mathrm{C}$ for $3500 \mathrm{hr}$.

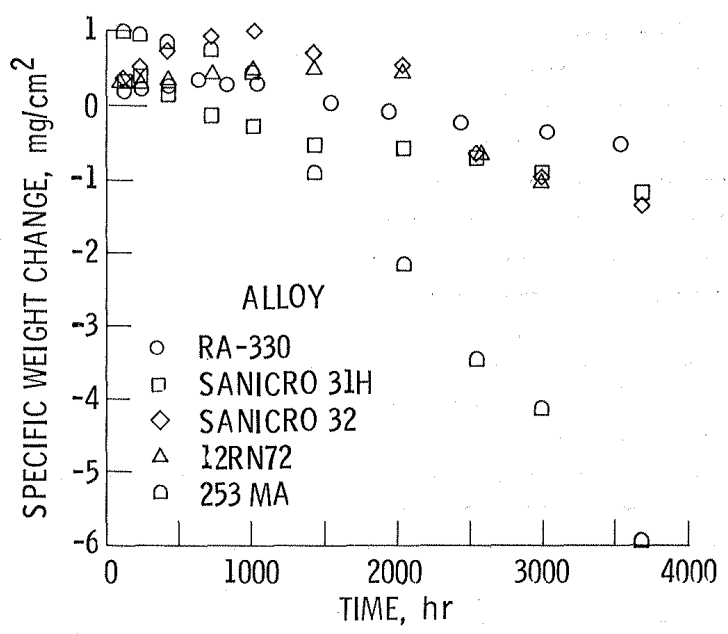

Figure 4. - Specific weight change data for group II alloys tested at $820^{\circ} \mathrm{C}$ for $3500 \mathrm{hr}$.

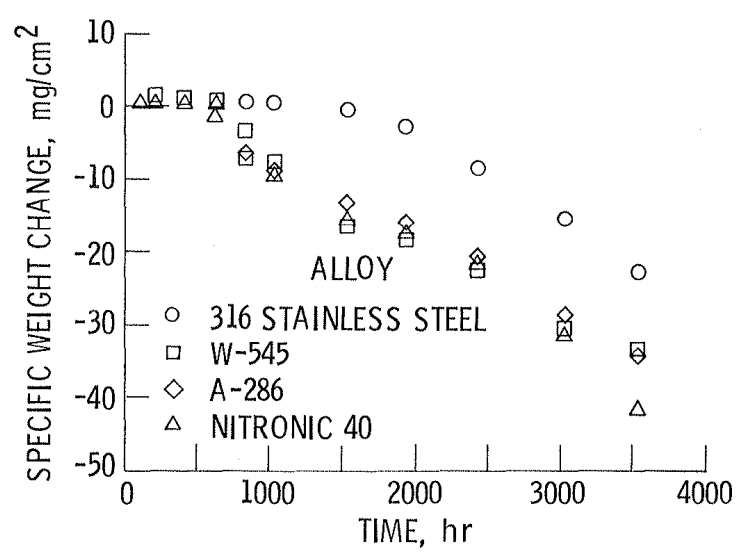

Figure 5. - Specific weight change data for group III alloys tested at $820^{\circ} \mathrm{C}$ for $3500 \mathrm{hr}$. 


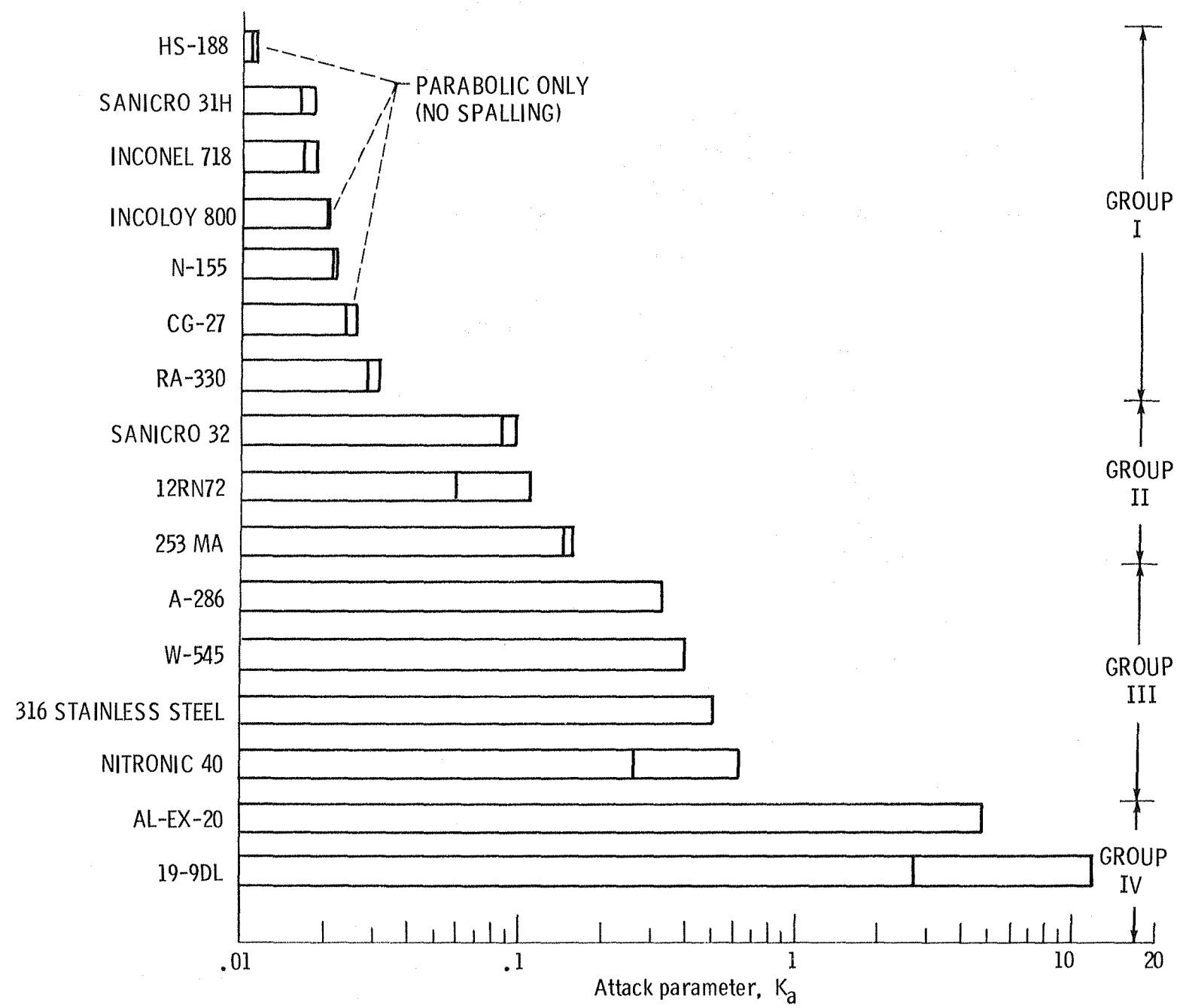

Figure 6. - Oxidation and corrosion attack parameter $K_{a}$ for 3500-hr cyclic exposure in Stirling engine simulator rig. Temperature, $820^{\circ} \mathrm{C}$; cycles length, $5 \mathrm{hr} ; \mathrm{K}_{\mathrm{a}}=\mathrm{k}_{1} / 2+10 \mathrm{k}_{2}$. (Duplicate samples.) 

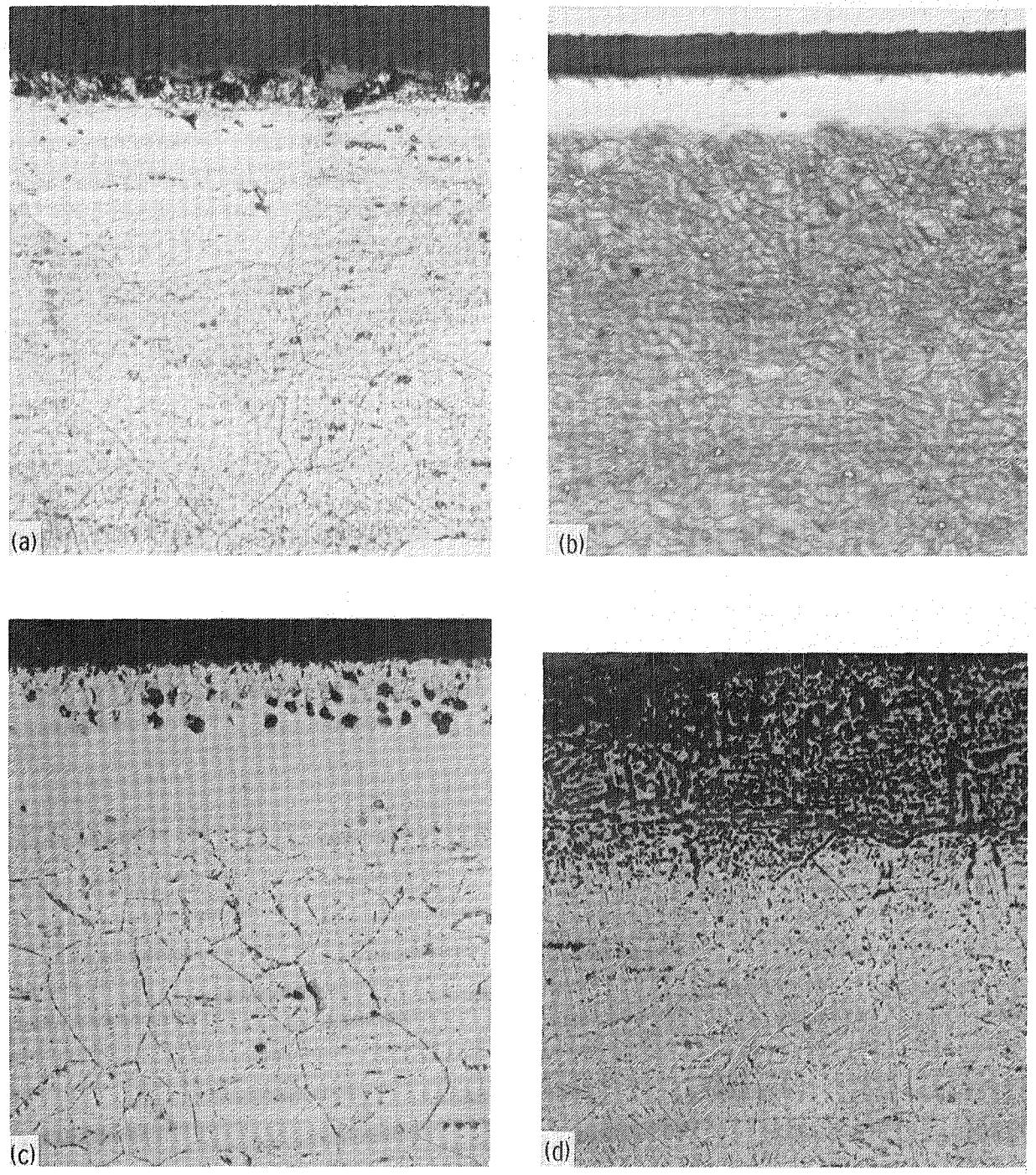

(a) CG-27.

(b) Inconel 718.

(c) Sanicro 32.

(d) $W-545$.

Figure 7. - Photomicrographs of selected $3500 \mathrm{hr}$ oxidation and corrosion test specimens. Longitudinal view showing surface scales and depletion zones; magnification, 250. 

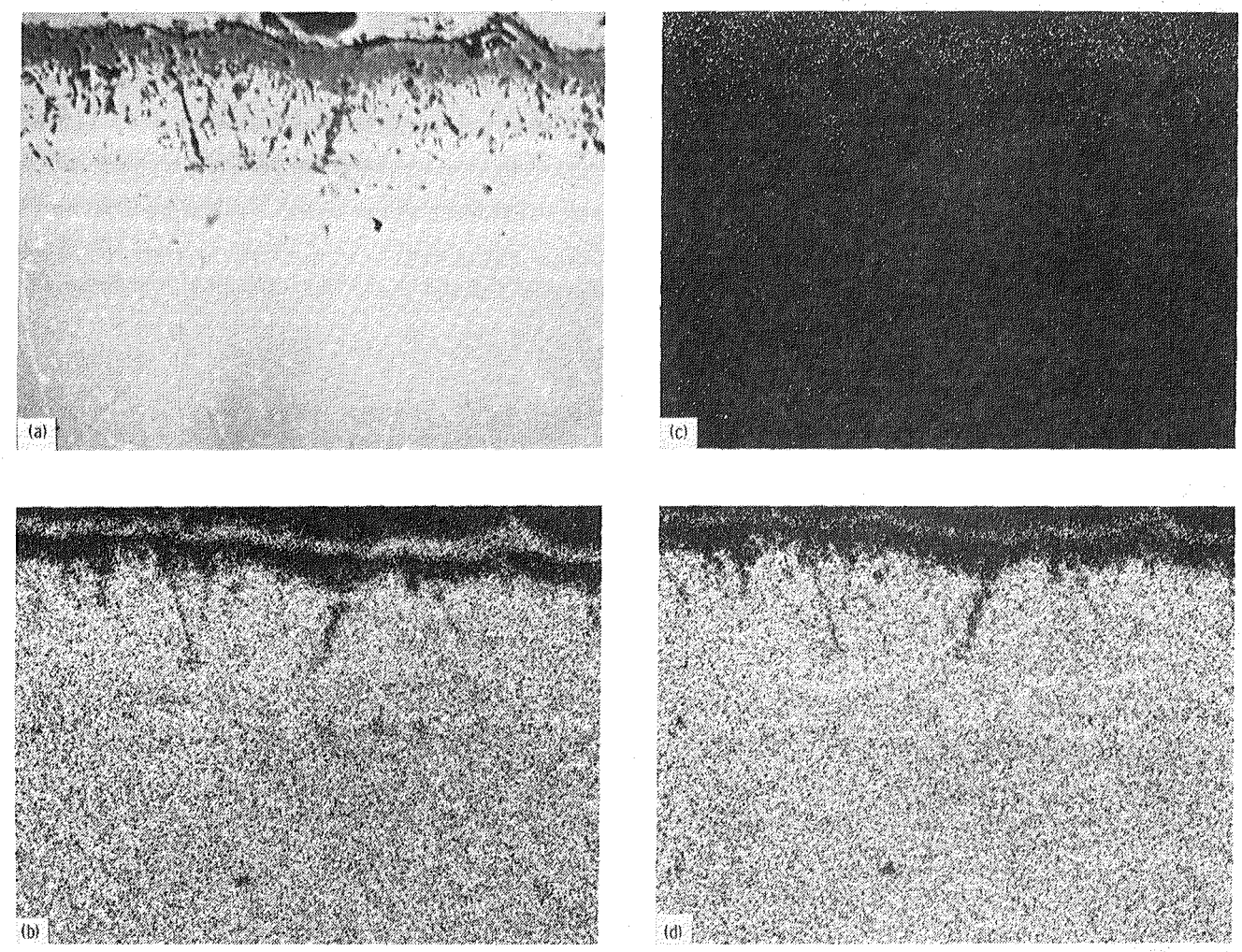
(a) BSE.
(c) Oxygen.
(b) Iron.
(d) Nickel.

Figure 8. - Electron microprobe analyses of alloy CG-27. Magnification, 1000. 

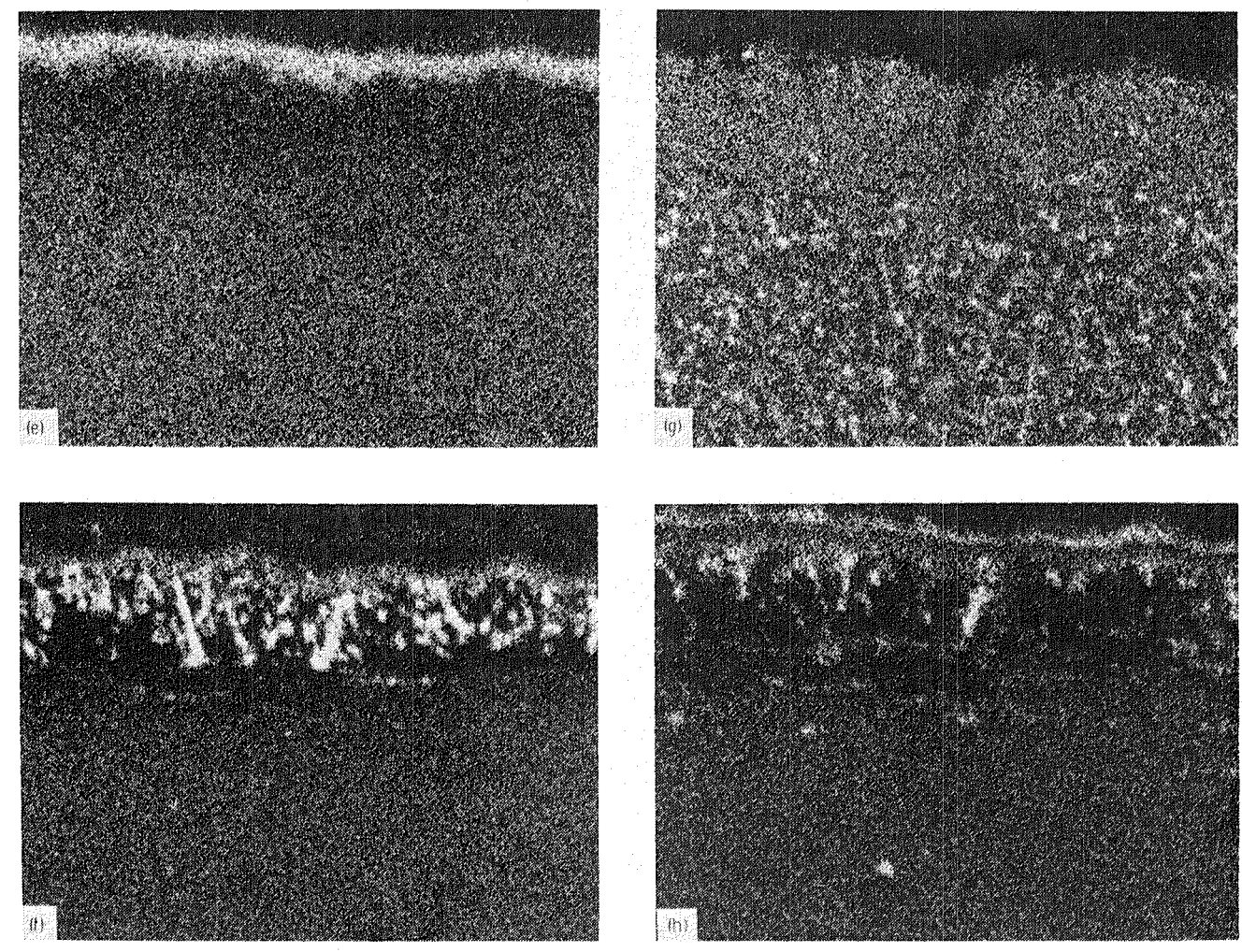

(e) Chromium.

(g) Molybdenum.

(f) Aluminum.

(h) Titanium.

Figure 8. - Concluded. 

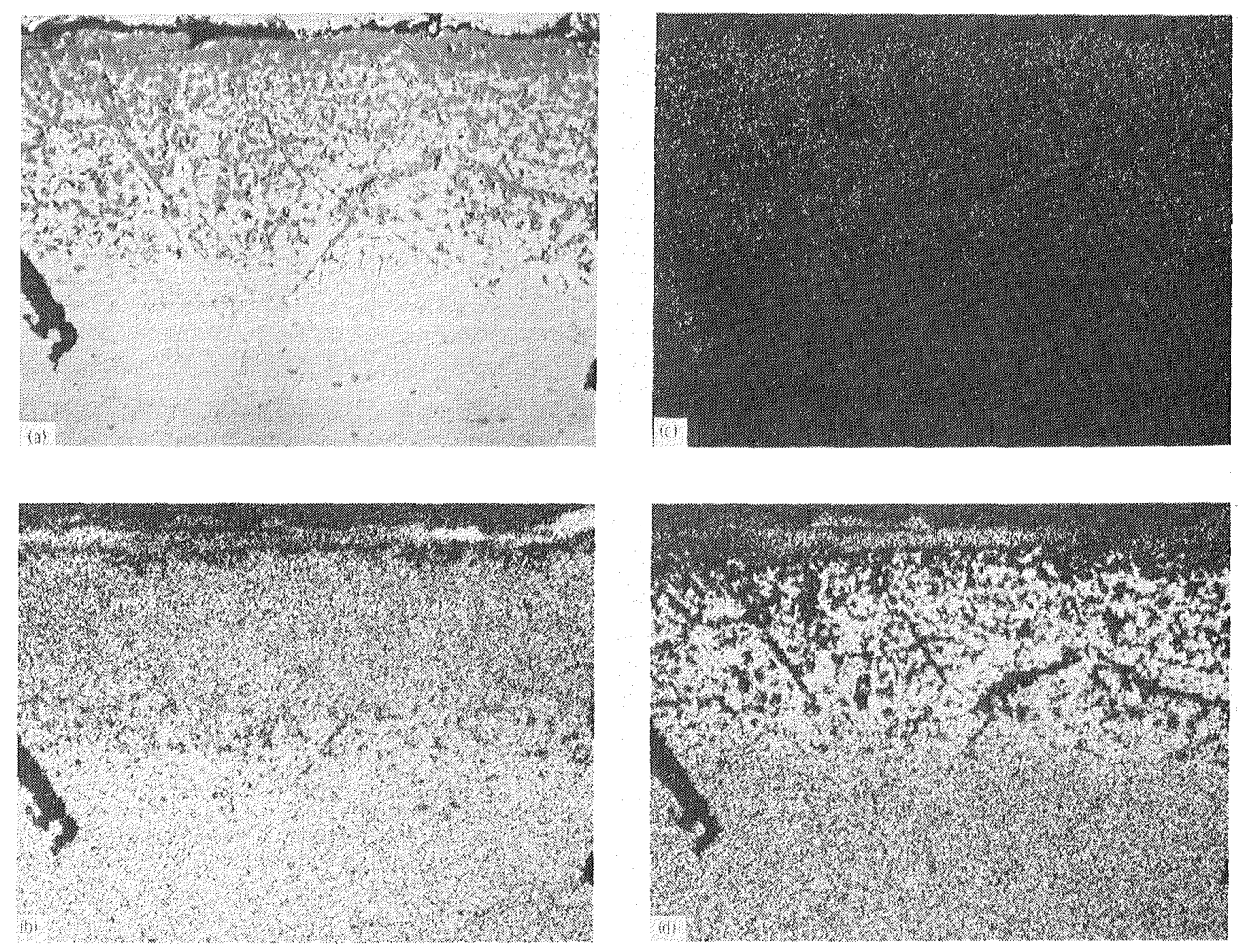

(a) BSE.

(c) Oxygen.

(b) Iron.

(d) Nickel.

Figure 9. - Electron microprobe analyses of alloy W-545. Magnification, 300. 

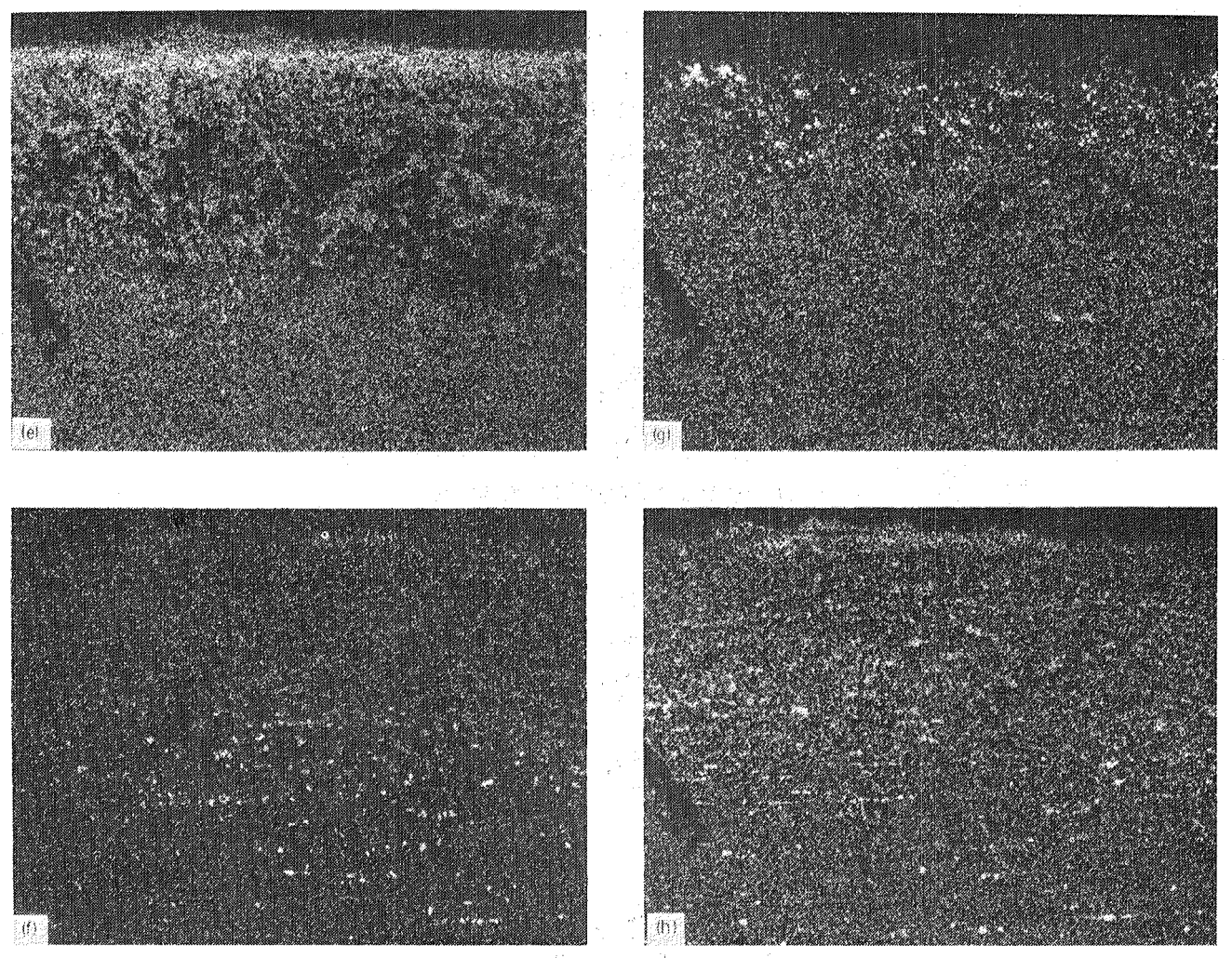

(e) Chromium.

(g) Molybdenum.

(f) Aluminum.

(h) Titanium.

Figure 9. - Concluded. 


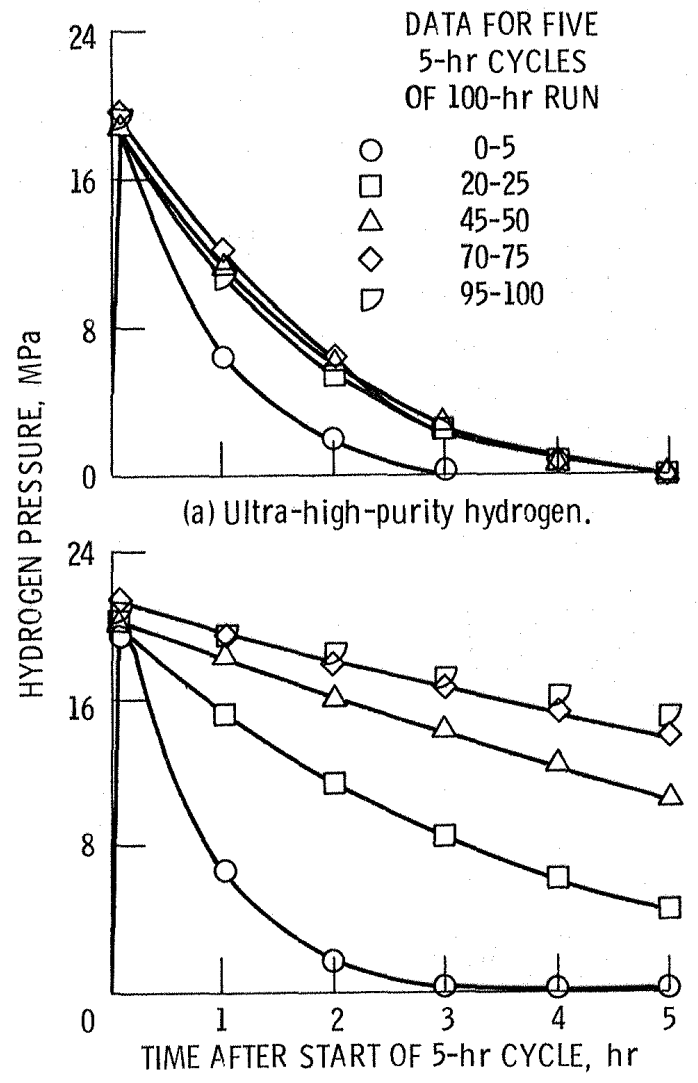

(b) Hydrogen doped with $\mathrm{I}$ vol $\% \mathrm{CO}_{2}$.

Figure 10. - Pressure decay curves for $\mathrm{N}-155$ at $820^{\circ} \mathrm{C}$. 


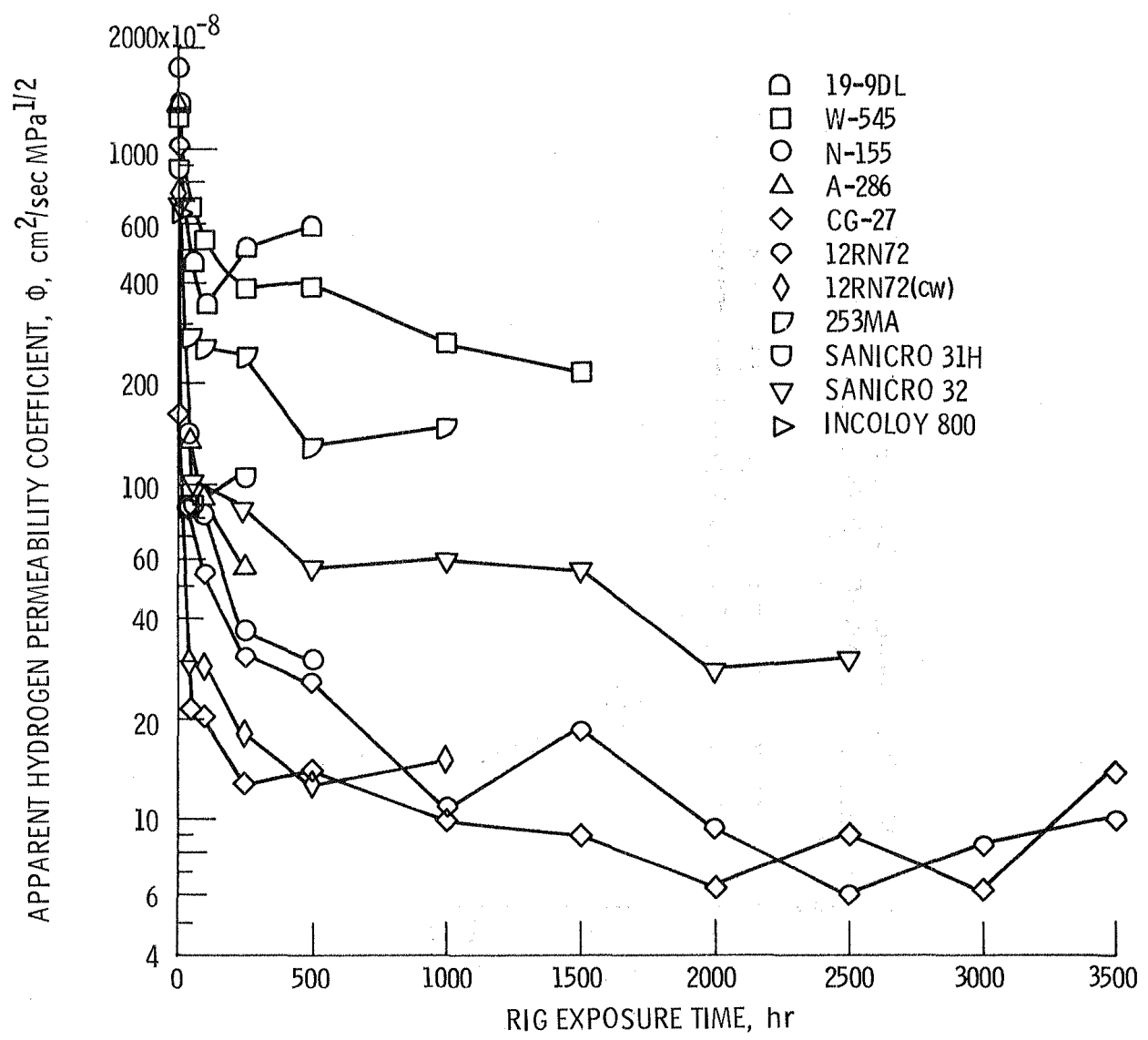

Figure 11. - Hydrogen permeability coefficient $\Phi$ versus rig exposure time for iron base alloys tested at $820^{\circ} \mathrm{C}$ with $\mathrm{H}_{2}+1 \% \mathrm{CO}_{2}$ at $15 \mathrm{MPa}$.

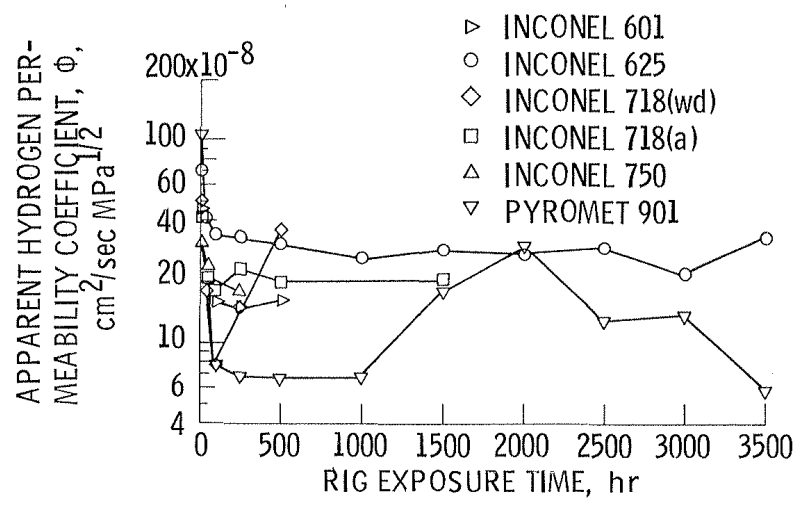

Figure 12. - Hydrogen permeability coefficient $\Phi$ versus rig exposure time for nickel base alloys tested at $820^{\circ} \mathrm{C}$ with $\mathrm{H}_{2}+1 \% \mathrm{CO}_{2}$ at $15 \mathrm{MPa}$. 


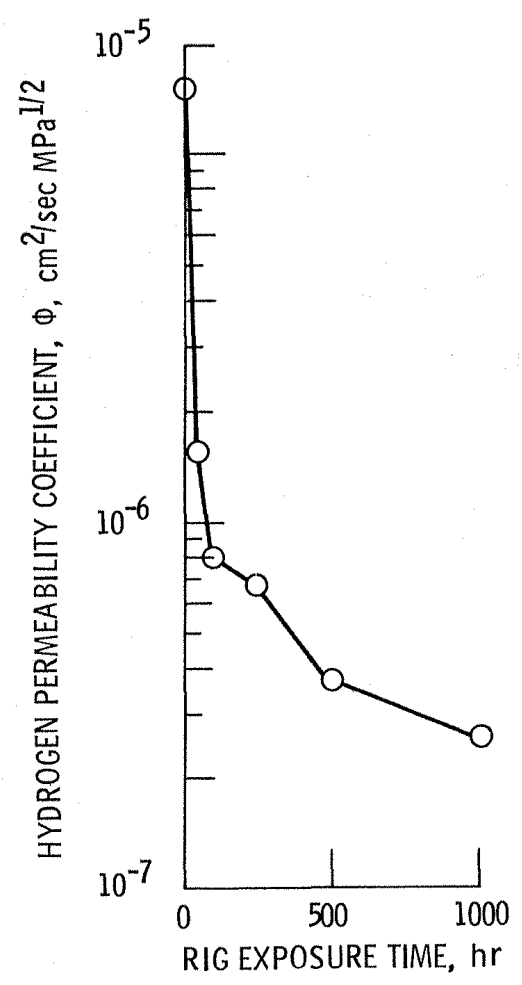

Figure 13. - Hydrogen permeability coefficient $\Phi$ versus rig exposure time for cobalt-base alloy HS-188 tested at $820{ }^{\circ} \mathrm{C}$ with $\mathrm{H}_{2}+1 \%$ $\mathrm{CO}_{2}$ at $15 \mathrm{MPa}$. 


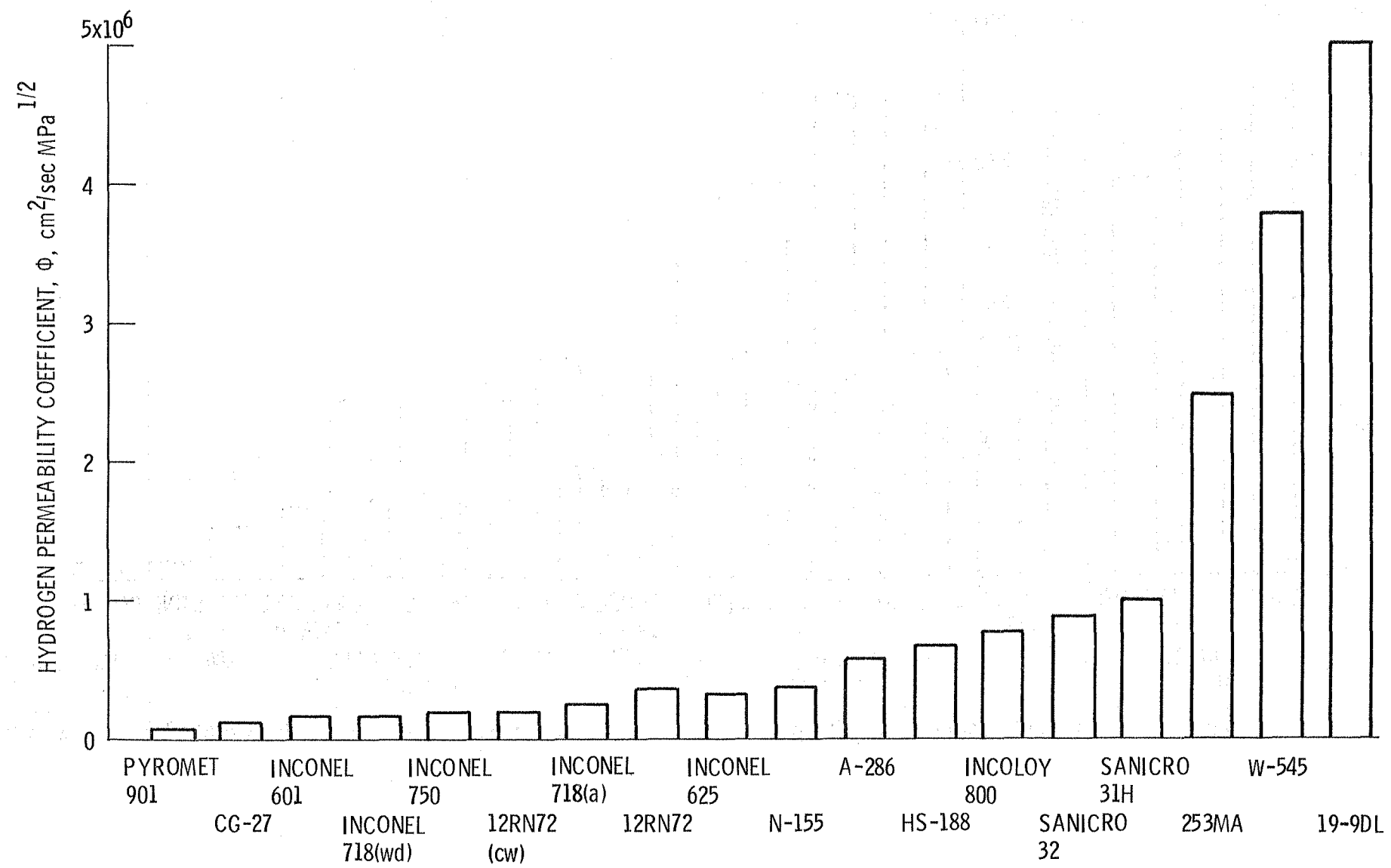

Figure 14. - Apparent hydrogen permeability coefficient at $250 \mathrm{hr}$ for tubing material endurance tested at $820^{\circ} \mathrm{C}$ and $15 \mathrm{MPa}$. 


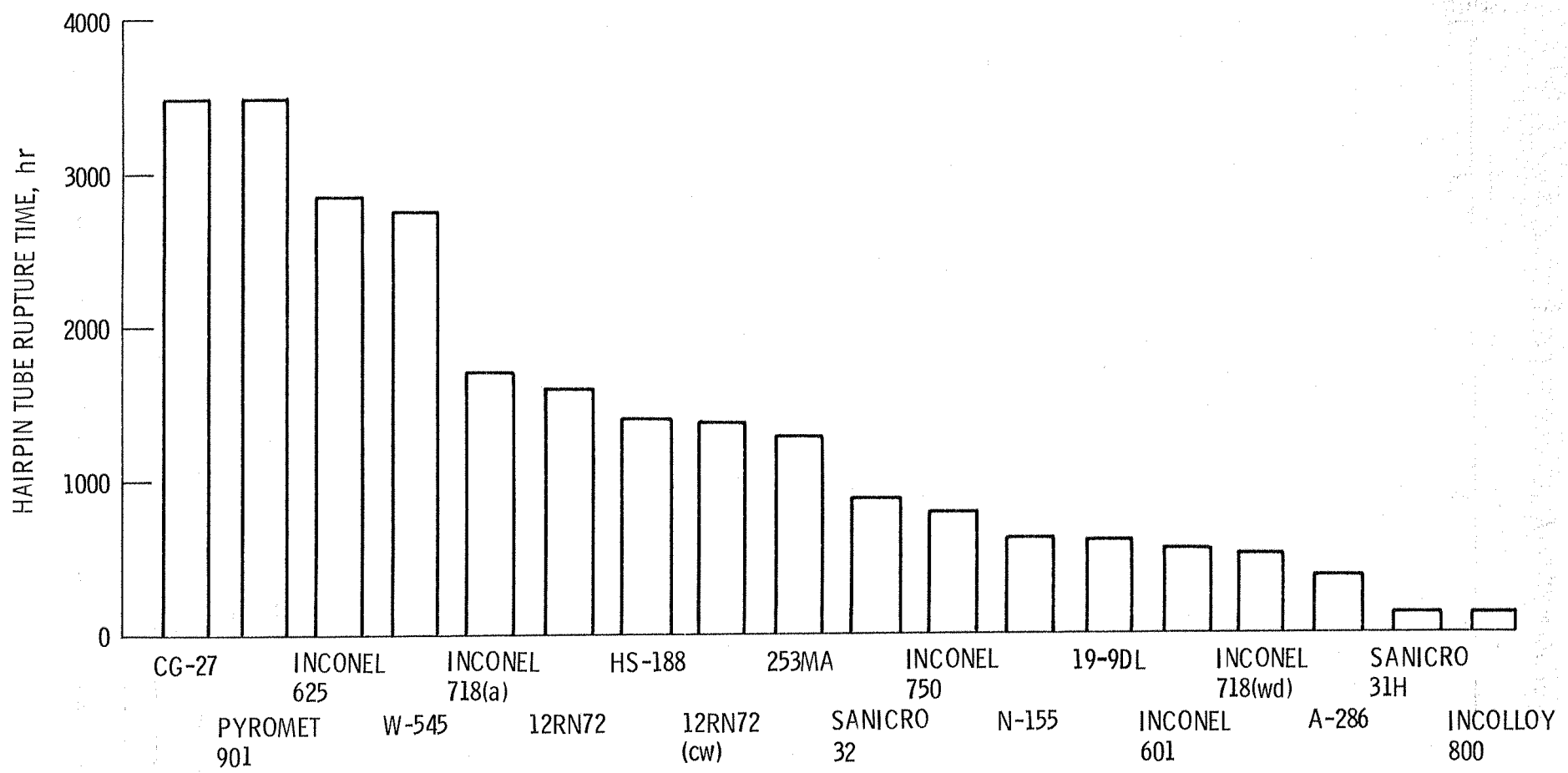

Figure 15. - Ranking of hairpin tubes according to rupture lives when pressurized with $15 \mathrm{MPa}$ helium at $820^{\circ} \mathrm{C}$. 


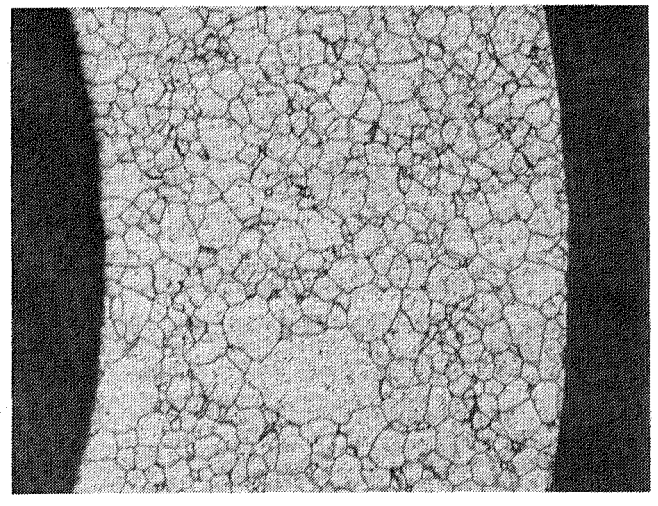

Unexposed

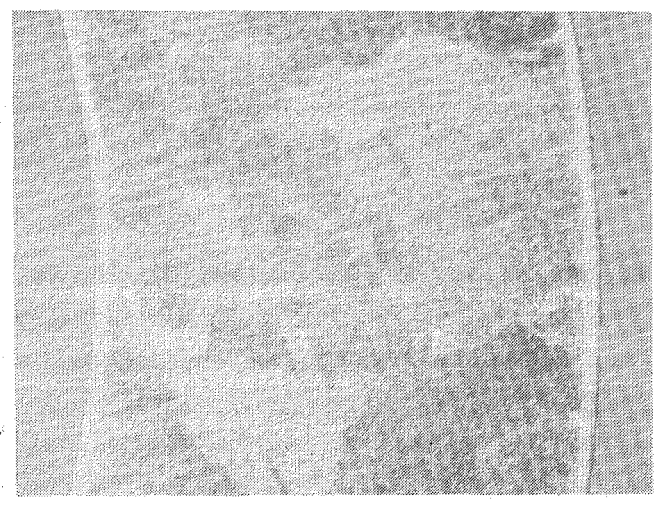

$\mathrm{H}_{2}-1 \% \mathrm{CO}_{2}$ exposed

(a) CG-27.

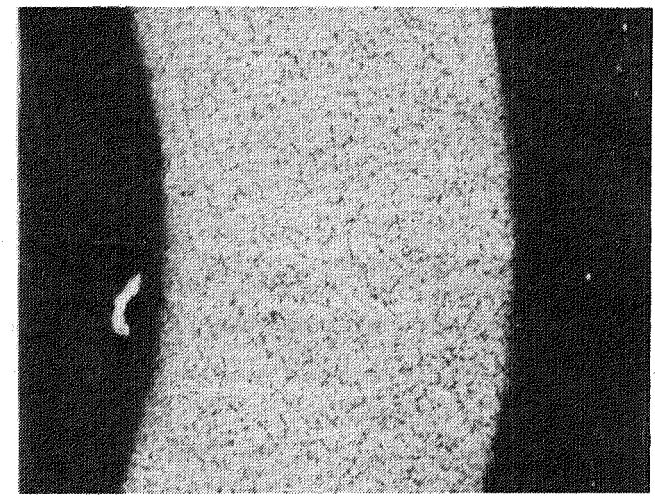

Unexposed

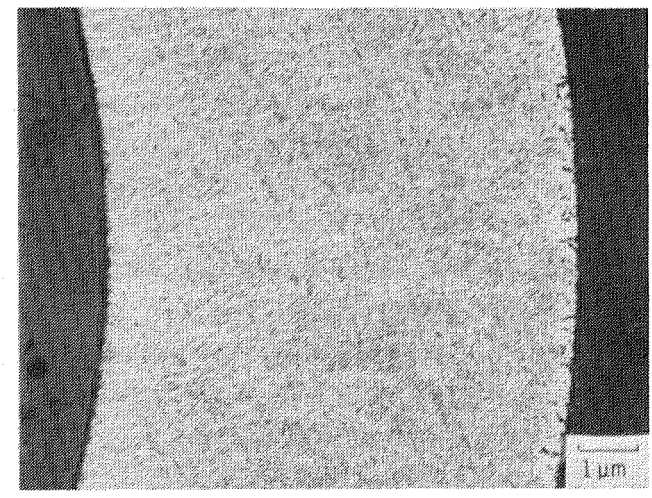

$\mathrm{H}_{2}+1 \% \mathrm{CO}_{2}$ exposed

(b) Inconel 625.

Figure 16. - Microstructures of hairpin tubes before and after rig exposure, $820^{\circ} \mathrm{C}, 3500 \mathrm{~h}$. 


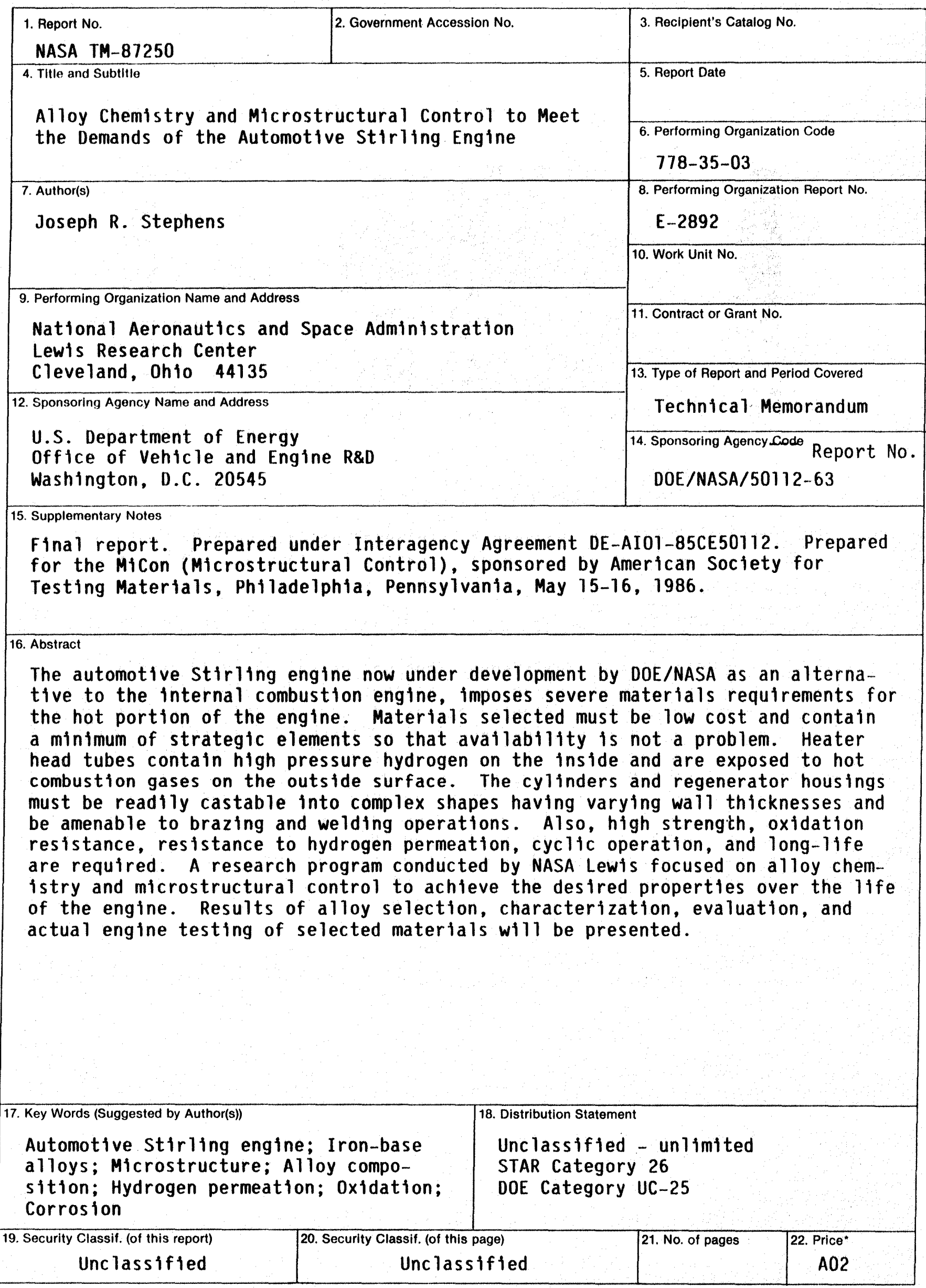

*For sale by the National Technical Information Service, Springfield, Virginia 22161 


\section{End of Document}

